\title{
Antibacterial Activity Test of Endophytic Fungus from Mangrove Plant (Rhizophora apiculata L.) and (Bruguiera gymnorrizha (L.) Lamk.) Against Klebsiella pneumoniae ATCC 700603
}

\section{Rossiana Nia, Miranti Mia, and Kosmita Oktapiana}

Laboratory of Microbiology, Department of Biology, Faculty of Mathematics and Natural Sciences, Universitas Padjadjaran, Jl, Raya Bandung-Jatinangor km 21, Indonesia

\section{Abstract}

Pathogenic bacteria Klebsiella pneumoniae is the cause of pneumonia disease in infants and adults. Antibiotics treatment is usually used to treat this disease. However, synthetic antibiotic use could lead to bacterial resistance. Therefore, novel antibiotics

Corresponding Author: Rossiana Nia niarossiana@yahoo.com

Received: 28 July 2017 Accepted: 14 September 2017 Published: 23 November 2017

Publishing services provided by Knowledge E

(c) Rossiana Nia et al. This article is distributed under the terms of the Creative

Commons Attribution License, which permits unrestricted use and redistribution provided that the original author and source are credited.

Selection and Peer-review under the responsibility of the ICSAFS Conference Committee.

\section{G OPEN ACCESS} from natural resources are required to overcome this problem. The aim of present study is to determine the antibacterial activity of endophytic fungal extracts from mangrove plants Rhizophoro opiculato and Bruguiero gymnorrhizo against $K$. pneumonio ATCC 700603 . Isolation, cultivation, extraction and antibacterial activity test were conducted. Fourteen endophytic fungi were derived from the two mangrove species, where the two fungal isolates: Penicilium sp.2 and Penicilium sp.4 showed the highest antibacterial activity. The minimum inhibitory concentration of $K$. pneumoniae for both fungal extract is $3.6 \mathrm{mg} \mathrm{mL}^{-1}$, where bactericidal effect was observed. Additionally, antibacterial activity from the extract of Penncillium sp.4 is higher compared to Penicilium sp.2 extract, which is signified by larger average diameter of inhibition zone. However, at concentration more than $3.6 \mathrm{mg} \mathrm{mL}^{-1}$, both extract effectively inhibit the growth of $K$. pneumonioe. Our study reveals the potential of fungal extract from mangrove plant as prospective drug candidate to overcome the pneumonia disease.

Keywords: antibacterial, pneumonia, endophytic fungi, mangrove.

\section{Introduction}

Infectious diseases are one of the biggest health problem in Indonesia and also in the world, and is a major cause of human mortality [1]. Pneumonia is the secondhighest deathly disease among children aged 0-5 years. The most important cause of pneumonia are Klebsiella pneumoniae bacteria [2]. $K$. pneumoniae is a Gram negative encapsulated, non-motile, rod-shaped, with a size of $0,3-1,5 \mu \mathrm{m} \times 0.6$ to $6.0 \mu \mathrm{m}$, and 
arranged single, in pairs or in short chains [3]. This bacterium is the biggest cause of pneumonia in infants and adults [4], with approximately $93 \%$ of them affected by pneumonia due to $K$. pneumoniae infection [5]. Treatments used for infections of pneumonia usually with antibiotics. However, improper antibiotic use can cause bacterial resistance. To overcome bacterial resistance material finding new antibiotics need to be done. In Indonesia, it has been reported that $K$. pneumoniae are resistant to a wide range of antibiotic substances, among others, co-trimoxazole, netilmicin, nalidixic acid, nitrofurantoin, gentamicin, ceftriaxone, amoksisilinas clavulanat, cefotaxime, amikacin, co-trimoxazole, ciprofloxacin, fosfomycin, cefuroxime, amoxicillin, chloramphenicol and ampicillin [6].

Finding antibiotic derived from nature needs to be done because of the use of antibiotics for pneumonia treatment, often cause several side effects. Mangrove is one of the unique ecosystems in the world with an area of only $2 \%$ of the earth's surface [7]. Mangrove ecosystem in Indonesia received more attention because of the unique characteristics. Mangroves are known to be rich in microbial biodiversity. Endophytic microbes that can be found are the endophytic fungi. Endophytic fungi found on the mangroves is very specific because of mangrove plants have different peculiarities with other plants [8].

Mangrove has long been known as a source of medicine traditional. Extracts from several species of mangrove plants such as Rhizophora stylosa, Soneratia griffithii, Kandelia candel, Aegiceras floridum and Excoecaria agallocha, known to inhibit bacterial growth due the secondary metabolic compounds produce, like flavonoids, saponins, tannins and alkaloids [9]. Mangrove ability to produce bioactive components is affected by endophytic microbes that live in the plant tissue. Potential bioactive compounds contained in plant mangrove resulted from the interaction between plants and endophytic microbes.

The interaction between the host plant endophytic fungi of mangrove, potentially act as bioactive compounds source, similar to the host plant. Endophytic fungi that live inside the plant network system capable of producing mycotoxins, enzymes, as well as an antibiotic substance produced as the host in an amount equal or higher [10]. Native mangrove endophytic fungi are a potential source for generating unique bioactive compounds that can be developed as an antibiotic [11]. The ability of endophytic microbes produce bioactive compounds is an opportunity in the provision of medicinal raw materials. Breeding or endophytic microbial cultures can be done in a very large number and short harvest time. Thus, the use of endophytic microbes as a source of medicinal raw materials is more economical $[12,13]$. Utilization of endophytic microbes as a source of natural medicine will also reduce the environmental damage caused by harvesting of medicinal plants in large quantities. It has been demonstrated 
that more than 10 types of endophytic microbes can be isolated from a single plant. These endophytes have the potential to produce one or more bioactive compounds against pathogenic bacteria [14]. Several researchers demonstrated that endophytic fungi isolated from mangroves Rhizophora apiculato and Bruguiera gymnorrhiza are known, have antibacterial activity against Gram positive and Gram negative bacteria $[15,16]$.

\section{Mangrove as Antibacterials}

Mangroves could produce secondary metabolites, an active antimicrobial compounds. Mangrove extract from mud and seawater was also able to inhibit the growth of pathogen Vibrio parahamolyticus. Mangrove plants also contain bioactive compounds such as saponins, flavonoids, alkaloids, and tannins. The active compounds have the ability as an antibacterial [17]. Organic and inorganic compounds such as phenolic acids, glycosides, alkaloids, proteins, flavonoids, terpenoids, steronoid, and metal compounds bound to organic compounds suspected to be used as agents for controlling bacteria, particularly the pathogenic bacteria. Bacterial growth is influenced by the difference in osmotic pressure inside and outside the cells, clotting proteins denatured in the cell, cell membrane irritation, changes in $\mathrm{pH}$, as well as emulsions and diffusion of fluid cells [18].

\section{Mangrove Endophytic fungi}

Mangrove is a rich source of host endophytic fungi, and fungi are endophytic microbes that most commonly found in mangrove ecosystem. Mangrove forest is source of marine microbial biodiversity because mangrove plants have different peculiarities with other plants. The top of the mangrove plants, stems and roots partly, very rare or even totally never contact with water. Terrestrial fungi inhabit the upper part of the mangrove plants. Whereas the bottom part, which is submerged by the seawater, inhabited by marine microorganisms, especially the marine fungi. At an intermediate point or transition between the top and the bottom part, there are also microorganisms that are capable of living in the area of transition, including fungi transition between terrestrial and marine fungi [8].

Fungi derived from mangrove are the second largest group of marine fungi. From 1500 species of marine fungi, at least 339 species can be found in the mangrove ecosystem. Aspergillus and Penicilium is a fungus that is predominantly found in the mangrove ecosystem. Mangrove is a special host plants and is a source of abundant 
endophytic fungi diversity. More than 200 species of endophytic fungi were isolated from mangrove plants [8].

\section{Klebsiella pneumoniae}

Friedlander is the person who first identified the bacteria $K$. pneumoniae from the lungs of people who died of pneumonia. Friedlander is an expert in pathology and microbiology from Germany who helped the discovery of the bacteria that cause pneumonia in 1882 [19]. K. pneumonioe can be distinguished from Enterobacter because of its ability to form immobile and thick mucus capsules. These bacteria can be conjugated with $E$. coli in the transfer of genetic and inflammation present in the lungs which is very dangerous [20] K. pneumoniae is widespread in soil, water, air, whole grains, and is normally present in the human and animals digestive tract. These bacteria can be infected human and animal through the air, food or water contaminated [3].

\section{Material and Methods}

The equipment used in this study is the glass ware (Merck), hot plate stirrer (Ika ${ }^{\circledR} \mathrm{C}$ Mag HS 7), incubator (ESCO), $\mathrm{CO}_{2}$ incubator (Sanyo), paper disc, laminar airflow cabinet level 2 (ESCO), refrigerator (Modena), micropipette (Thermo), analytical balance (Precisa), oven (ESCO), plastic wrap (Kingplan), shaker bath incubator (Techne SB-16), centrifuge tubes (Falcon), tip $1 \mathrm{ml}$ (Nunc), and vortex (Thermoyne).

Culture material used in this study is fourteen isolates of the fungus isolated from R. apiculato and B. gymnorrizha, and K. pneumoniae as test bacteria. Endophytic fungi used in the present study were isolated from $R$. apiculato and B. gymnorrhizo (the roots and leaves) in the National Park Alas Purwo mangrove forest area (TNAP). Nine fungi isolated from $R$. apiculata, four fungi of the genus Penicillium, two fungi of the genus Aspergillus, two fungi of the genus Rhizophus and one fungus of the genus Mucor. Five other fungi derived from B. gymnorrhiza, three fungi of the genus Penicillium, one fungus of the genus Mucor and one fungi of the genus Aspergillus. Media and chemicals used in this study is alcohol, aquabides, Muiler Hinton Agar (MHA) (Oxoid), Muiler Hinton Broth (MHB) (Oxoid), NaCl Physiological (Merck), Potato Dextrose Agar (PDA) (Oxoid), Potato Dextrose Broth (PDB) (Oxoid).

Fungal isolates screening test was conducted using disc diffusion method with modifications. The fourteen fungal isolates were tested their antibacterial activity against K. pneumoniae. The observed parameter was the large area formed fungal inhibitory to bacteria grown on media. The data were then analyzed descriptively. MIC testing fungi extract from $R$. apiculato and B. gymnorrizho (based on the results of screening tests) 


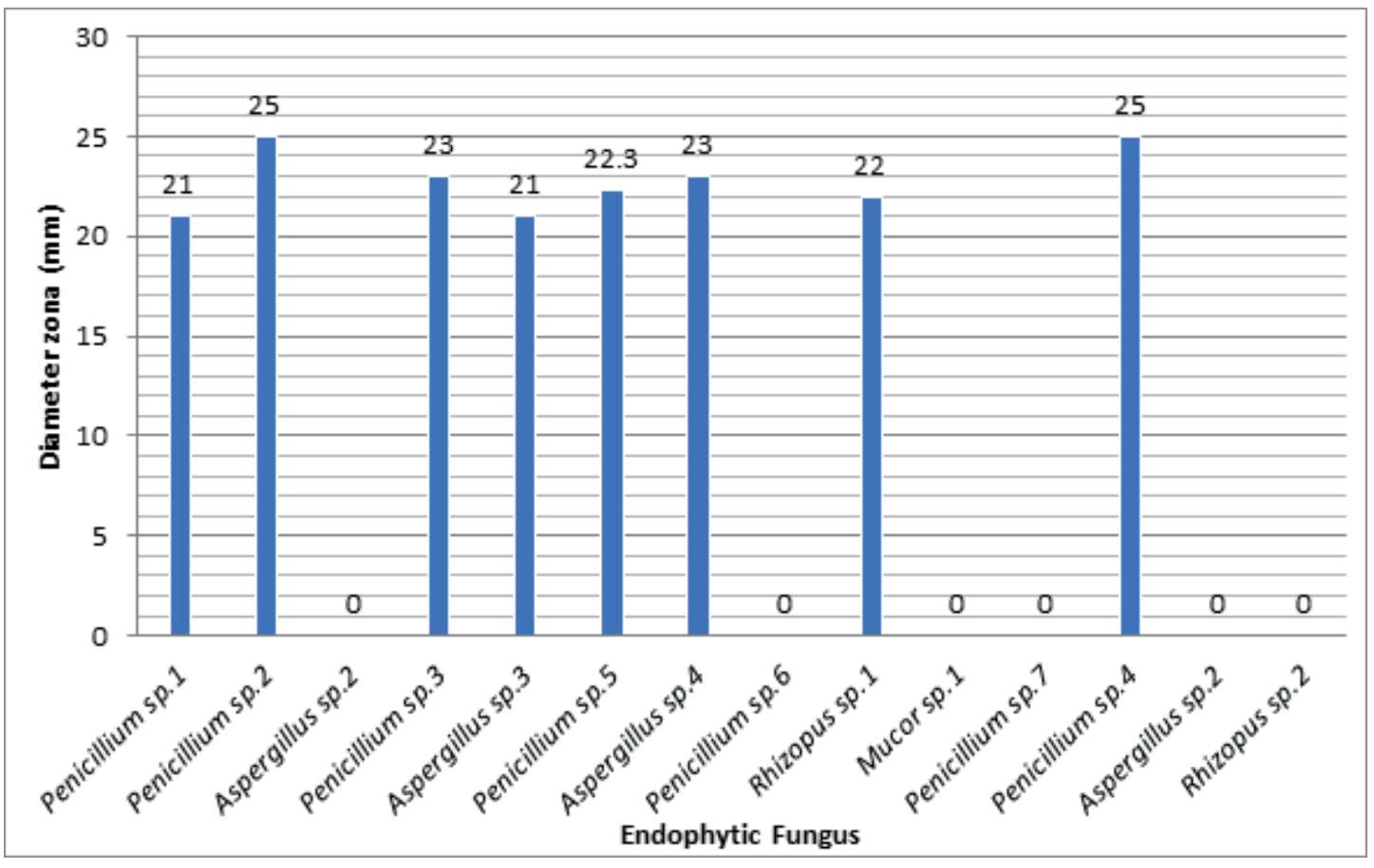

Figure 1: Antibacterial Activity of Endophytic Fungus against $K$. pneumoniae.

against $K$. pneumonioe carried by the liquid dilution method. Fungal extracts selected based screening test was made in several concentrations $(4.5 ; 4.275 ; 4.05 ; 3.825 ; 3.6$; $3.375 ; 3.15 ; 2.925 ; 2.7 ; 2.475 ; 2.25 ; 2.025 ; 1.8 ; 1.575 ; 1.35 ; 1.125 ; 0.9 ; 0.675 ; 0.45 ;$ and 0.225 $\mathrm{mg} \mathrm{mL}^{-1}$ ). Parameters measured were the presence or absence of bacterial growth by streaking suspensions on bacteria medium. Data were then analyzed descriptively. Effectiveness of fungi extracts on the inhibition of the growth of $K$. pneumoniae ATCC 600703 was performed by disc diffusion method. The concentration of the extract used in this test was based on the value of the MIC. Parameters measured were the magnitude of the inhibitory region formed by the fungi extracts against $K$. pneumoniae bacteria, then the data were analyzed descriptively.

\section{Results and Discussion}

\subsection{Antibacterial Activity of Endophytic Fungus R. apiculata origin and B. gymnorrhiza}

Results of antibacterial activity test of fourteen fungal isolates against $K$. pneumoniae as follows.

From 14 fungal isolates of $R$. apiculato and B. gymnorrhiza tested against the bacteria K. pneumonioe, 8 fungal isolates exhibited antibacterial activity. While six other fungal isolates did not show any antibacterial activity, indicated by the absence of inhibition 


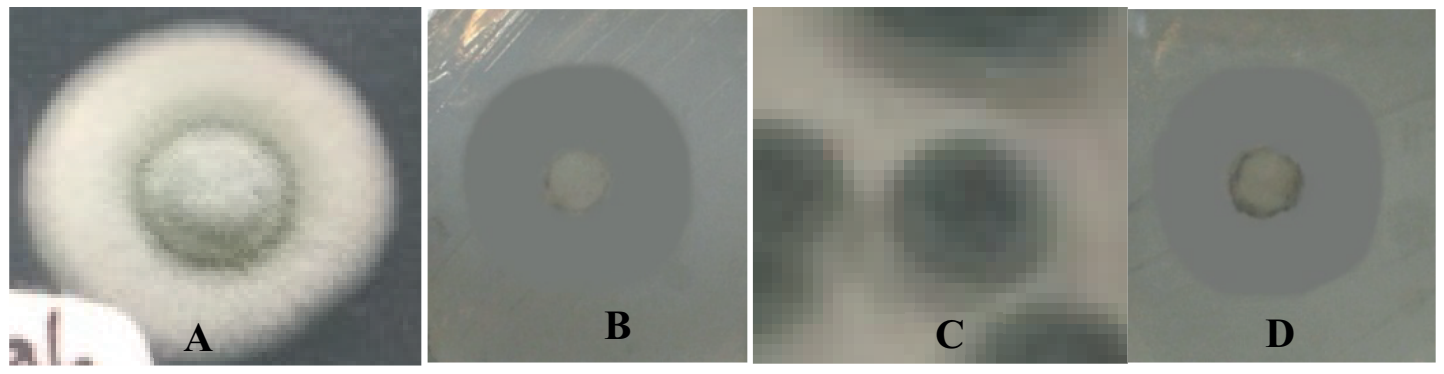

Figure 2: A. Penicillium sp.2, B. Diameter of inhibition zone that formed by Penicillium sp.2, C. Penicillium sp.4, D. Diameter inhibition zone formed by Penicillium sp.4.

zones formed. Eighth isolates that have the antibacterial activity were Penicillium sp.1, Penicillium sp.2, Penicillium sp.3, Aspergillus sp.3, Penicillium sp.5, Aspergillus sp.4, Rhizopus sp.1 and Penicillium Sp.4; with the average diameter of the inhibition zones of $21,25,23,21,22.3,23,22$ and $25 \mathrm{~mm}$, respectively. The diameter of inhibition zone formed by Penicillium sp.2 and Penicillium sp.4 were $25 \mathrm{~mm}$, then classified into very strong category, because more than $20 \mathrm{~mm}$ [21]. The ability of substances tested to inhibit bacterial growth can be caused by several factors, including the type of fungi. Each type of fungi has different capabilities in inhibiting bacteria because each type of fungus produces different compounds, in terms of both quantity and quality.

Inhibition zone formed around the discs indicates fungi antibacterial activity. The formation of inhibition zone indicates that these fungi produce compounds that inhibit the growth of tested bacteria. Inhibition of bacteria due to the reaction of chemical compounds as antibacterial agent. The compounds are predominantly found in the extract mangrove endophytic fungi origin, including flavonoids, saponins, tannins and alkaloids. Mechanism of action flavonoids as antibacterial is by denaturing proteins in the bacterial cell cytoplasm and damage the membrane. Flavonoids can damage the cytoplasmic membrane, which can cause leaking of important metabolites and inactivating bacterial enzyme systems. This damage allows the nucleotide and amino acid oozes out and prevented the entry of active ingredients into the cells, thus causing bacterial death [22]. In addition, Saponin compounds can damage the cytoplasmic membrane [23]. Damage on cytoplasmic membrane results reduction in cell membrane permeability, and uncontrolled substances transportation into the cell and release from the cell. Substances that are within the cell such as organic ion enzymes, amino acids and nutrients can get out of the cell. When the cell release the enzyme along with substances such as water and nutrients can cause metabolic inhibited resulting in decreased ATP needed for the growth and proliferation of cells, then inhibited the growth of bacterial cell and cause cell death. Saponin could be expected to penetrate cell wall. Then same mechanism was applied which lead to inhibition of bacterial cell growth [24]. The alkaloid is a class of compounds that are found in fungi, has the ability 
as an antibacterial. The mechanism by interfering with peptidoglycan component of the bacterial cell wall layer of cells that are not fully formed, disruption of peptidoglycan synthesis so that cell formation is not perfect. This situation causes the bacterial cells susceptible to lysis, either physical or osmotic and cause cell death.

K. pneumoniae is a Gram negatively with thick cell wall structure, consisting of Porin, distinctive lipopolysaccharide (which is an essential component of bacteria in causing disease), lipoprotein and thin peptidoglycan layer. The thickness cell wall of $K$. pneumonioe is strong enough to protect them from the outside environment, but selective molecules can enter the cell through Porin, including antibacterial agents. Bacterial resistance to anti-bacterial agents may also occur because of a mismatch molecule of antibacterial agents against a target site or incompatibility mechanism of inhibition of the antibacterial agent against metabolic pathway owned by $K$. pneumoniae. Both factors might occur on the six fungi that cannot inhibit the $K$. pneumoniae. In contrast to the eight fungi that are capable of inhibiting $K$. pneumonioe, similarity was observed between the target molecule and antibacterial agent site inhibitory metabolic pathway or mechanism, which owned by bacteria [25].

\subsection{MIC of extract Penicillium Sp.2 and Penicillium Sp.4 in inhibiting bacteria $K$. pneumoniae}

Effects of various concentrations of extracts of Penicillium sp.2 and Penicillium sp.4 on the growth of $K$. pneumoniae was described as follows.

In observation of the turbidity of the liquid dilution in MIC test, the extract of both fungus $3.375 \mathrm{mg} \mathrm{mL}^{-1}$, showed that there was an increase in turbidity of liquid, which indicates bacterial growth. In contrast, no turbidity was observed on the liquid extract at $3.6,3.825,4.05,4.275$ and $4.5 \mathrm{mg} \mathrm{mL}^{-1}$. Thus, the value of $K$. pneumoniae MIC is $\mathrm{mg}$ $\mathrm{mL}^{-1}$ in both fungal extract. MIC test results showed that the fungus extracts were bactericidal at concentrations of $3.6,3.825,4.05,4.275$ and $4.5 \mathrm{mg} \mathrm{mL}^{-1}$, while at concentration of 0.225 to $3.375 \mathrm{mg} \mathrm{mL}^{-1}$, were bacteriostatic (inhibits bacterial growth).

Increased turbidity from the clear liquid is an indicator of the presence or absence of bacterial growth. Growth is an increase in the number or volume and cell size. Increasing bacterial cells is proportionally with the turbidity of liquid. Additionally, increase in fluid turbidity occurs due to compounds production by bacterial cells. Growth of the organism in an environment is highly influenced by various environmental factors, including physical and chemical factors that can affect growth rate of an organism [26].

The growth of $K$. pneumoniae, in the medium exposed to the fungus extract (24 hours incubation), showed different response to each concentration of the extract. 
The response might be due to differences during the growth adaptation phase. Adaptation phase is a phase in which bacteria adept to the substrate and environmental conditions. Basically, microorganisms that are placed in an environment with the new conditions, needs to adapt with the environment before the cells multiply. Moreover, microorganisms need time to form a new enzyme to break down the new substrate [19]. When the microbes can adapt to the environment, then the microbes can grow. Conversely, death occurs when the microbes are not able to adapt, or when the environment is too toxic to microbes.

K. pneumoniae could not pass through adaptation phase to grow on the medium with a minimum concentration of $3.6 \mathrm{mg} \mathrm{mL}^{-1}$, in an environment exposed to the fungal extract indicating bactericidal effect of the extracts. Therefore, fugal extracts have an inhibitory effect (bacteriostatic effect) on the growth of bacteria, depends on its concentration.

\subsection{Effectiveness of Fungus Extract}

Test on the effectiveness of the extract was conducted to determine the effect of different fungi extract concentration on the growth inhibition of $K$. pneumonia. Growth Inhibition is presented in Table 2.

The inhibition zone formed by Penicillium sp.4 extract at each concentration appeared to be larger than the Penicillium sp.2 (Table 2), indicating $K$. pneumoniae is more sensitive to Penicillium sp.4. Extract with MIC of $3.6 \mathrm{mg} \mathrm{mL}^{-1}$, was able to produce diameter inhibition zone of $25 \mathrm{~mm}$ and categorized as strong antibacterial activity.

Both yeast extract at $3.375 \mathrm{mg} \mathrm{mL}^{-1}$ resulted in 9 and $10 \mathrm{~mm}$ of inhibition zone for Penicillium sp.2 and Penicillium sp.4, respectiveley. Based on the inhibition zone, which is less than or equal to $10 \mathrm{~mm}, K$. pneumoniae was considered less sensitive at this. Interestingly, at concentration of 3.6 and $3.825 \mathrm{mg} \mathrm{mL}^{-1}$ of the extract, antibacterial activity increased, indicated by inhibitory diameter that ranged between $10 \mathrm{~mm}$ to 20 $\mathrm{mm}$ ). At higher concentrations, c.a. 4.05, 4.275 and $4.5 \mathrm{mg} \mathrm{mL}^{-1}$, exhibited extremely strong antibacterial activity with the inhibition zone more than $20 \mathrm{~mm}$. The first two range of concentration was comparable with the inhibition zone of streptomycin as positive control. Our result was in coherence with previous study where the bacteria are very sensitive to both concentrations [20]. 
TABle 1: Effect of various concentrations of extracts of the fungus Penicillium sp.2 and Penicillium sp.4 on the growth of $K$. pneumonioe.

\begin{tabular}{|c|c|c|c|c|c|}
\hline \multirow[t]{2}{*}{ No } & \multirow[t]{2}{*}{ Extract concentration $\left(\mathrm{mg} \mathrm{mL}^{-1}\right)$} & \multicolumn{2}{|c|}{ MIC test (Dilution method) } & \multicolumn{2}{|c|}{ Confirmation test (Streak method) } \\
\hline & & Penicillium sp.2 & Penicillium sp.4 & Penicillium sp.2 & Penicillium sp.4 \\
\hline 1 & Control & $\checkmark$ & $\checkmark$ & + & + \\
\hline 2 & 0.225 & $\checkmark$ & $\checkmark$ & + & + \\
\hline 3 & 0.45 & $\checkmark$ & $\checkmark$ & + & + \\
\hline 4 & 0.675 & $\checkmark$ & $\checkmark$ & + & + \\
\hline 5 & 0.9 & $\checkmark$ & $\checkmark$ & + & + \\
\hline 6 & 1.125 & $\checkmark$ & $\checkmark$ & + & + \\
\hline 7 & 1.35 & $\checkmark$ & $\checkmark$ & + & + \\
\hline 8 & 1.575 & $\checkmark$ & $\checkmark$ & + & + \\
\hline 9 & 1.8 & $\checkmark$ & $\checkmark$ & + & + \\
\hline 10 & 2.025 & $\checkmark$ & $\checkmark$ & + & + \\
\hline 11 & 2.25 & $\checkmark$ & $\checkmark$ & + & + \\
\hline 12 & 2.475 & $\checkmark$ & $\checkmark$ & + & + \\
\hline 13 & 2.7 & $\checkmark$ & $\checkmark$ & + & + \\
\hline 14 & 2.925 & $\checkmark$ & $\checkmark$ & + & + \\
\hline 15 & 3.15 & $\checkmark$ & $\checkmark$ & + & + \\
\hline 16 & 3.375 & $\checkmark$ & $\checkmark$ & + & + \\
\hline 17 & 3.6 & $x$ & $x$ & - & - \\
\hline 18 & 3.825 & $x$ & $x$ & - & - \\
\hline 19 & 4.05 & $x$ & $x$ & - & - \\
\hline 20 & 4.275 & $x$ & $x$ & - & - \\
\hline 21 & 4.5 & $x$ & $x$ & - & - \\
\hline Cont & trol: MHB + Bacteria & & + : Bacteria grov & wth & \\
\hline$\checkmark: I$ & Increased turbidity & & - : No bacteria $g$ & growth & \\
\hline
\end{tabular}

\section{Conclusion}

The present study showed that from the fourteen endophytic fungi that have been tested against $K$. pneumoniae ATCC 700 603, two fungal isolates showed the highest antibacterial activity, namely Penicillium sp.2 and Penicillium sp.4. The minimum 
TABLE 2: Effect of different concentration of the herbal extract isolate on growth inhibition of $K$. pneumonioe.

\begin{tabular}{|c|c|c|c|}
\hline \multirow[t]{2}{*}{ No } & \multirow[t]{2}{*}{ Extrat Concentration $\left(\mathrm{mg} \mathrm{mL}^{-1}\right)$} & \multicolumn{2}{|c|}{ Average of diameter of inhibition zone formed by fungi (mm) } \\
\hline & & Penicillium sp.2 & Penicillium sp.4 \\
\hline 1 & $3 \cdot 375$ & 9 & 10 \\
\hline 2 & 3.6 & 17 & 18 \\
\hline 3 & 3.825 & 19 & 20 \\
\hline 4 & 4.05 & 22 & 23 \\
\hline 5 & 4.275 & 23 & 24 \\
\hline 6 & 4.5 & 24 & 25 \\
\hline
\end{tabular}

inhibitory concentration of $K$. pneumoniae for both fungal extract is $3.6 \mathrm{mg} \mathrm{mL}^{-1}$, where bactericidal effect was observed. The extract Penicillium sp.4 have better antibacterial activity compared to Penicillium sp.2 extract, which is signified by larger average diameter of inhibition zone. However, both extracts at concentration more than $3.6 \mathrm{mg}$ $\mathrm{mL}^{-1}$, effectively inhibit the growth of $K$. pneumoniae ATCC 700603 .

\section{References}

[1] Mulholland, E. K., Kartika, dan Adegbola, R. A. 2005. Bacterial Infection- A Major Cause of Death among Childern in Africa. The New England Journal Medicine. 352: 75-77.

[2] Riskedas

[3] Pelczar, M.J. dan E.C.S. Chan. 2006. Dasar-dasar Mikrobiologi (diterjemahkan oleh Ratna Siri Hadioetomo). Jilid 2. Ul-Press. Jakarta.

[4] Maldonado, N.C., de Ruiz, C.S., M. Cecilia., dan M.E. Nader-Macias. 2007. A Simple Technique to Detect Klebsiella Biofilm-Forming Strains: Inhibitory Commuication. Current Research and Educational Topics and Trends in Applied Microbiology. A Mendez-Vilas (Ed): 52-59.

[5] Nelwan, R. 2002. Pemakaian Antimikroba Secara Rasional Di Klinik. Dalam: Noer S, Editor. Buku Ajar Ilmu Penyakit Dalam. Penerbit FKUI. Jakarta.

[6] Subandiyah, Krisni. 2004. Pola Dan Sensitivitas Terhadap Antibiotik Bakteri Penyebab Infeksi Saluran Kemih Anak Di RSU Dr Saiful Anwar, Malang. Jurnal Kedokteran Brawijaya, 20:2. 
[7] Setyawan, A.D. and Winarno, K. 2006. Direct utilization of mangrove ecosystem in Central Java dan land use in surrounding: damage and restoration efforts. Jurnal Biodiversitas. 7(3), 282-291.

[8] Kim, Se-Kwon. 2015. Springer Handbook of Marine Biotechnology. Springer-Verlag Berlin Heidelberg.

[9] Kokpol, U. 1987. Procedings of Unesco Regional Seminar On The Chemistry Of Mangrove Plants.Chualalongkorn University. Bangkok.

[10] Selim K, El-beih A, Abdel R. and El-Diwany A. 2012.Biology of endophytic fungi. Current Research in Environmental \& Applied Mycology.2:35.

[11] Nair S, Sasirekha N, Appunu C, Bharathkumar, Loganathan, Rameshkumar N, Sridhar $\mathrm{R}$, Subathra G Prabhavathy VR. 2000. Microbial diversity in Mangrove ecosystem: A Review. Biobytes 3:1-6

[12] Kumala, S. dan Fitri, N. A. 2008.Screening of endophyticfungi of Shorea balangeran Korth bark as xylanase source. Jurnal Ilmu Kefarmasian Indonesia.6(1),1- 6.

[13] Sinaga, E., Noverita, dan Fitria, D. 2009. Antibacterial activity of endophytic fungi isolated from leaves of Alpinia galangal SW. Jurnal Farmasi Indonesia. 4(4), 161-170.

[14] Sandhu SS, Suneel K, Aharwal RP, Shukla H and Rajak RC. 2014. Endophytic Fungi: As A Source of Antimicrobials Bioactive Compounds. World J Phar Pharmac Sci. 3(2):1179-1197.

[15] Kartika, R., W. Bodhi, B. Kepel, dan R. Bara. 2010. Uji Daya Hambat Jamur Endofit Akar Bakau Rhizophora apiculata Terhadap Bakteri S. aureus Dan E.coli. Kimia FK Univ. Sam Ratulangi.

[16] Phoanda, Tilesky C., Robert Bara, P. M. Wowor, dan Jimmy Posangi. 2014. Uji Efek Antibakteri Jamur Endofit Akar Tumbuhan Bakau (Bruguiera gymnorrhiza) Terhadap Bakteri E. coli \& S. aureus. Farmakologi dan Terapi FK Univ. Sam Ratulangi. Manado.

[17] Naiborhu, P.E. 2002. Ekstraksi \& Manfaat Ekstrak Mangrove (S.alba Dan S.caseolaris) Sebagai Bahan Alami Antibakterial Pada Patogen Udang Windu, Vibrio harveyi. Thesis.IPB.

[18] Hasyim, T.K. 2014. Sensitivitas bakteri E.coli ATCC 25922, S.aureus ATCC 25923, dan wild type (E.coli dan S.aureus) penyebab diare terhadap ekstrak isolate jamur yang diisolasi dari Sargassum cinereum J.Agardh. Skripsi. Progran Studi Biologi FMIPA UNPAD. Skripsi.

[19] Nurhajati, J.,Chrysanti, dan Fauziah, P.N. 2013. Isolasi dan Identifikasi mikroorganisme beserto teknik laboratorium. Alfabeta. Bandung.

[20] Fauziah, P.N. 2012. Penghambatan Adhesi Berbagai Strain Klebsiella pneumoniae Oleh Lactobacillus bulgaricus Dalam Soyghurt Secara In Vitro Pada Hep-2 Cell Lines Dengan Berbagai Proses Perlakuan Infeksi. Skripsi. Progran Studi Biologi FMIPA UNPAD. 
[21] Tarman, K., Safitri, D. and Setyaningsih, I. 2013. Endophytic Fungi Isolated from Rhizophora mucronato and Their Antibacterial Activity. Squalen Bulletin of Marine $\&$ Fisheries Postharvest \& Biotechnology, 8 (2), 2013, 69-76.

[22] Prajitno, Arief. 2007. Uji Sensitifitas Flavonoid Rumput Laut (Eucheuma Cottoni) Sebagai Bioaktif Alami Terhadap Bakteri Vibrio Harveyi. Skripsi. Fakultas Perikanan, Universitas Brawijaya

[23] Aulia, Ismi Arsyi. 2008. Uji aktivitos Antibakteri Fraksi Etil Asetat Ekstrak Etanolik Daun Arbenan (duchesnea indica (andr.) Focke) Terhadap Staphylococcus aureus dan Pseudomonas aeruginosa Multiresisten Antibiotik Beserto Profil Kromatografi Lapis Tipisnya.On_line.Skripsi.Tersedia di:http://etd.eprints.ums.ac.id/1517/1/ K100040115.pdf. diakses 28 februari 2015.

[24] Ajizah, A, Thihana, dan Mirhanuddin. 2007. Potensi Ekstrak Kayu Ulin (Eusideroxylon zwageri) Dalam Menghambat Pertumbuhan Bakteri Staphylococcus aureus Secara In Vitro. Skripsi.On_line.Tersedia di:http://bioscientiae.unlam.ac.id/v4n1/v4n1_ajizah.pdf.Diakses 20 Mei 2015.

[25] Coyle, Marie B. 2005. Manual of Antimicrobial Susceptibility Testing. American Society for Microbiology (ASM).

[26] Nurhidayah, Ikeu, Sari, Fatimah, dan Windy, R,. 2008. Upaya Keluarga dalam pencegahan dan perawaton ISPA di Rumah pada Balita di kecamatan Ciawi Kabupaten Tasikmalaya. (Dok. Fakultas IImu Keperawatan Unpad). 